\title{
OPTIMALISASI PENGEMBANGAN PERENCANAAN PERKULIAHAN DARING MATA KULIAH BAHASA INDONESIA UNIVERSITAS TJUT NYAK DHIEN MEDAN
}

\author{
Dila Handayani, Fitry Wahyuni \\ Surel: dilahandayani1@gmail.com
}

\begin{abstract}
The purpose of this research is to optimize it by developing recoveryplanning starting from Lecture Contracts, SAP and RPS, Evaluation and Digital Book Teaching Materials in Indonesian Language courses. This type of research is research and development. The research and development steps are guided by the ADDIE model (Analyze, Design, Development, Implementation, Evaluation). The results of the Validator Review of Learning Planning Experts for Online Lectures for Indonesian Language Coursesat Tjut Nyak Dhien University stage 1, for lecture contracts, SAP \& RPS and Evaluation, the number is 33 with a percentage of $76.7 \%$ and the category is feasible. Review of the Validator of Learning Planning Online Lectures for Indonesian Language Course at Tjut Nyak Dhien University phase 2, for lecture control, SAP, RPS and Evaluation the total is 43 with a percentage of $100 \%$ and the category is very feasible. Digital book validation research on Optimizing the Development of Online Lecture Learning Planning for Indonesian Language Courses at Tjut Nyak Dhien University is $80.5 \%$. The results obtained on the results of student lectures from several meetings obtained an increase in UTS scores with a percentage of $94 \%$. The conclusion of the research results obtained are the results of expert validation of Lecture Contracts, SAP, RPS, Evaluation and Digital Book Teaching Materials that are suitable for use in Optimizing the Development of Learning Planning for Online Lectures for Indonesian Language Courses at Tjut Nyak Dhien University.
\end{abstract}

Keywords: Optimization, Development, Planning, Online, Indonesian

ABSTRAK
Tujuan penelitian ini untuk untuk mengobtimalisasikan dengan mengembangkan perencanaan perkulihan mulai dari Kontrak Perkuliahan, SAP dan RPS, Evalusi dan Bahan Ajar Digital Book pada mata kuliah Bahasa Indonesia. Jenis penelitian ini merupakan penelitian pengembangan (Research and Development). Langkah-langkah penelitian dan pengembangan berpedoman pada model ADDIE (Analyze, Design, Development, Implementation, Evaluation). Hasil Riview Validator Ahli Perencanaan Pembelajaran Perkuliahan Daring Mata Kuliah Bahasa Indonesia Universitas Tjut Nyak Dhien tahap 1, untuk kontrak kuliah, SAP \& RPS dan Evaluasi mendapat jumlah 33 dengan persentasi 76,7 \% dan katagori layak. Riview Validator Ahli Perencanaan Pembelajaran Perkuliahan Daring Mata Kuliah Bahasa Indonesia Universitas Tjut Nyak Dhien tahap 2, untuk kontral kuliah, SAP, RPS dan Evaluasi mendapat jumlah 43 dengan persentasi $100 \%$ dan katagori sangat layak. Penelitian validasi digital book pada Optimalisasi Pengembangan Perencanaan Pembelajaran Perkuliahan Daring Mata Kuliah Bahasa Indonesia Universitas Tjut Nyak Dhien adalah $80,5 \%$. Hasil yang diperoleh pada hasil perkuliahan mahasiswa dari beberapa pertemuan memperoleh peningkatan nilai UTS dengan presentasu $94 \%$. Kesimpulan hasil penelitian yang diperoleh yakni hasil validasi ahli terhadap Kontrak kuliah, SAP, RPS, Evaluasi dan Bahan Ajar Digital Book layak digunakan dalam Optimalisasi Pengembangan Perencanaan Pembelajaran Perkuliahan Daring Mata Kuliah Bahasa Indonesia Universitas Tjut Nyak Dhien.

Kata Kunci: Optimalisasi, Pengembangan, Perencanaan, Daring, Bahasa Indonesia 
Dila Handayani, Fitry Wahyuni : Optimalisasi Pengembangan ...

\section{PENDAHULUAN}

Mata kulian Bahasa Indonesia bertujuan agar mahasiswa dapat menjelaskan kedudukan dan fungsi bahasa Indonesia, bahasa Indonesia baku; mengeksplorasi teks akademik dalam genre makro; menjelajah dunia pustaka; mendesain proposal penelitian dan proposal kegiatan; melaporkan hasil penelitian dan hasil kegiatan; dan mengaktualisasikan diri melalui artikel ilmiah. Metode perkuliahan yang berjalan selama ini pada umumnya menggunakan metode ceramah, diskusi, penugasan makalah dan praktek. Namun, masih banyak ditemukan mahasiswa yang pasif. $\mathrm{Hal}$ ini dibuktikan dengan hasil ujian yang mendapatkan nilai formatif $70 \%$ hanya mendapat kategori cukup kompeten. Masih ada $30 \%$ mahasiswa yang tidak kompeten. Berdasarkan masalah di atas maka peneliti merencakan Optimalisasi Perencanaan Pembelajaran mata kuliah Bahasa Indonesia direncanakan dengan sistem perkulihan daring digunakan secara tepat dan jelas. Maka dibuatlah gagasan pemecahan isu yakni 'Optimalisasikan

Perencanaan

Perkuliahan Daring dengan pengembangan Silabus, RPS, Evaluasi perkuliahan daring dan Bahan Ajar yang dibuat dalam bentuk digital book'. Dengan alasan tersebut juga peneliti berinisiatif membuat $e$ Book yang kreatif, interaktif, manarik dan informatif. Dengan demikian diharapkan penyampaian materi elektronika digital lebih maksimal, semakin mudah dipahami oleh peserta didik, peserta didik tidak merasa bosan dalam menerima pelajaran, serta dapat termotivasi untuk mempelajari lebih lanjut. Selain itu, dengan e-Book diharapkan peserta didik tidak hanya termotivasi pada saat pelajaran berlangsung tetapi juga termotivasi untuk belajar di luar jam pelajaran dan mampu bereksperimen terkait dengan materi yang disampaikan. Selain itu juga mahasiswa diberikan materi tambahan guna memahami lebih luas materi yang mungkin belum bisa tersampaikan langsung ketika melaksanakan perkuliahan daring. Mengatasi permasalahan yang ada seperti perencanaan perkuliahan diperkaya dan menarik bagi mahasiswa sehingga dapat diakses kapan pun dan dimana saja.

Berdasarkan latar belakang masalah diatas, maka perumusan masalah dalam penelitian ini adalah : (1) Apakah Pengembangan Perencanaan Pembelajaran Perkuliahan Daring Mata Kuliah Bahasa Indonesia berupa digita book pada mata kuliah Bahasa Indonesia yang dikembangkan memenuhi syarat valid berdasarkan kriteria isi, tampilan, dan bahasa?, (2) Bagaimana respon peserta didik terhadap penggunana Perencanaan Pembelajaran Perkuliahan Daring Mata Kuliah Bahasa Indonesia berupa digita book?

Tujuan penelitian adalah : (1) Untuk membuat Pengembangan Perencanaan Pembelajaran Perkuliahan Daring yang memenuhi syarat (valid) sebagai pembelajaran interaktif pada mata Bahasa Indonesia. (2) Mendeskripsikan respon 
mahasiswa terhadap penggunaan Pengembangan

Perencanaan

Pembelajaran Perkuliahan Daring pada mata kuliah Bahasa Indonesia.

METODE PENELITIAN
Peneliti menggunakan metode research and development $(\mathrm{R} \& \mathrm{D})$ dari model R\&D ADDIE (Analysis, Design, Development, Implementation, and Evaluation). Bagan prosedural pada penelitian ini adalah berikut ini :

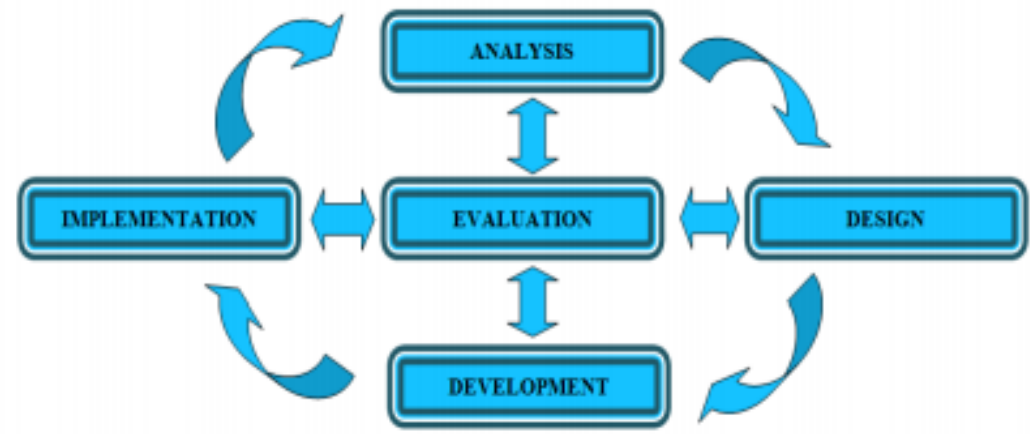

Gambar 1. Metode Rese arch and Development (R\&D) Model ADDIE

Langkah-langkah prosedur penelitian dapat dijabarkan sebagai berikut:

1. Analyze (Analisis), bertujuan untuk mengetahui apa saja yang dibutuhkan dalam pengembangan media pembelajaran ini. Analisisanalisis tersebut akan diurakan sebagai berikut:

a. Analisis Kurikulum. Analisis kurikulum dilakukan dengan mempertimbangakan materi yang akan dikembangkan dalam media, menyesuaikan dengan Standar Kompetensi (SK), Kompetensi Dasar (KD), dan indikator pencapaian peserta didik yang harus dicapai sesuai dengan materi pokok.

b. Analisis Karakter. Peserta Didik Untuk mengetahui karakteristik peserta didik yaitu dengan melakukan wawancara kepada pendidik yang mengajar di kelas tersebut.

c. Analisis Kebutuhan. Tujuan analisis kebutuhan adalah untuk mengetahui perihal yang dibutuhkan peserta didik atau pendidik dalam interaksi pembelajaran

2. Design (Perencanaan). Tahap kedua adalah tahap pembuatan rancangan dari materi, desain, dan instrumen-instrumen yang akan digunakan dalam tahap pengembangan.

3. Development (Pengembangan). Proses pengembangan dilakukan dengan mengimport rancangan materi desain dan lainnya ke aplikasi yang telah ditentukan sebelumnya. 
Dila Handayani, Fitry Wahyuni : Optimalisasi Pengembangan ...

4. Implemetation (Implementasi).

Tahap selanjutnya adalah pelaksanaan ujicoba produk kepada peserta didik dengan tujuan untuk mengetahui tingkat kemenarikan media tersebut.

5. Evaluation (Evaluasi). Tahap evaluasi merupakan tahap akhir dari setiap langkah-langkah pengembangan di atas.

Pengumpulan data penelitian ini dilakukan berdasarkan:

1. Angket. Dokumen hasil instrumen-instrumen validasi dan angket respon peserta didik yang akan dipergunakan untuk mengetahui tingkat kelayakan sehingga digital book dapat digunakan dalam kegiatan belajar mengajar.

2. Observasi. Kegiatan observasi yang dilakukan oleh peneliti secara langsung mengamati ke proses perkuliahan.

Instrumen penelitian yang digunakan diisi dengan cara checklist pada setiap indikator untuk mengetahui tingkat kelayakan produk. Apabila tingkat kelayakan produk belum cukup maka validator memberikan saran atau masukan untuk acuan perbaikan.

\section{HASIL PENELITIAN DAN} PEMBAHASAN

Optimalisasi Pengembangan

Perencanaan Pembelajaran

Perkuliahan Daring Mata Kuliah Bahasa Indonesia Universitas Tjut Nyak Dhien menggunakan model ADDIE (Analysis, Design, Develop, Implement, and Evaluate). Alasan pemilihan model ADDIE dikarenakan langkah-langkah penelitian model ADDIE lebih terstruktur dan interaktif. Berikut merupakan penjelasan dan hasil analis is dari kegiatan penelitian.

Tabel 1. Hasil Riview Validator Ahli Perencanaan Pembelajaran Perkuliahan Daring Mata Kuliah Bahasa Indonesia Universitas Tjut Nyak Dhien

\begin{tabular}{|c|c|c|c|}
\hline Krite ria Penilaian & $\begin{array}{l}\text { Jumlah } \\
\text { Maks } \\
\text { Skor }\end{array}$ & $\begin{array}{l}\text { Skore } \\
\text { Dicapai }\end{array}$ & Klasifikasi \\
\hline Kontrak Kuliah & 8 & 6 & Layak \\
\hline SAP & 12 & 9 & Layak \\
\hline $\begin{array}{ll}\text { Rencana } & \text { Pelaksanaan } \\
\text { Perkuliahan } & \end{array}$ & 12 & 9 & Layak \\
\hline Evaluasi & 11 & 9 & Layak \\
\hline Jumlah Keseluruhan & 43 & 33 & $33 / 43=76,7 \%$ \\
\hline
\end{tabular}

Pada tabel 1 dapat dijelaskan bahwa Hasil Riview Validator Ahli Perencanaan Pembelajaran Perkuliahan Daring Mata Kuliah
Bahasa Indonesia Universitas Tjut Nyak Dhien tahap 1, untuk kontral kuliah, SAP, RPS dan Evaluasi mendapat jumlah 33 dengan 
persentasi $76,7 \%$ dan katagori layak.

Tabel 2. Hasil Riview Validator Ahli Perencanaan Pembelajaran Perkuliahan Daring Mata Kuliah Bahasa Indonesia Universitas Tjut Nyak Dhien

\begin{tabular}{|c|c|c|c|}
\hline Kriteria Penilaian & $\begin{array}{l}\text { Jumlah } \\
\text { Maks } \\
\text { Skor }\end{array}$ & $\begin{array}{l}\text { Skor } \\
\text { Dicapai }\end{array}$ & Klasifikasi \\
\hline Kontrak Kuliah & 8 & 8 & Sangat Layak \\
\hline SAP & 12 & 12 & Sangat Layak \\
\hline $\begin{array}{l}\text { Rencana } \\
\text { Perkuliahan }\end{array}$ & 12 & 12 & Sangat Layak \\
\hline $\begin{array}{l}\text { Evaluasi } \\
\text { Jumlah Keseluruhan }\end{array}$ & $\begin{array}{l}11 \\
43\end{array}$ & 11 & $\begin{array}{l}\text { Sangat Layak } \\
43 / 43=100 \%\end{array}$ \\
\hline
\end{tabular}

Pada tabel 2 dapat dijelaskan bahwa Hasil Riview Validator Ahli Perencanaan Pembelajaran Perkuliahan Daring Mata Kuliah Bahasa Indonesia Universitas Tjut Nyak Dhien tahap 2, untuk kontral kuliah, SAP, RPS dan Evaluasi mendapat jumlah 43 dengan persentasi $100 \%$ dan katagori sangat layak. Hasil validasi kelayakan perencanan pembelajaran sejalan dengan hasil penelitian Syahbana (2012:21), yaitu berdasarkan hasil pengembangan perangkat pembelajaran yang dilakukan telah memenuhi kriteria valid. Valid tergambar dari hasil penilaian validator bahwa semua validator menyatakan baik berdasarkan content (sesuai kurikulum), konstruk (sesuai karakteristik/prinsip pembelajaran) dan bahasa (sesuai dengan bahasa yang berlaku yaitu ejaan yang disempurnakan). Hasil validator ahli materi dan media terhadap Bahan Ajar Digital Book Optimalisasi Pengembangan Perencanaan Pembelajaran Perkuliahan Daring Mata Kuliah Bahasa Indonesia Universitas Tjut Nyak Dhien sebagai berikut:

Tabel 3. Hasil Validasi Ahli Materi dan Media Bahan Ajar Digital Book

\begin{tabular}{lllll}
\hline Krite ria Penilaian & Nomor & $\begin{array}{l}\text { Jumlah } \\
\text { Maks Skor }\end{array}$ & $\begin{array}{l}\text { Score } \\
\text { Dicapai }\end{array}$ & Klasifikasi \\
\hline Muatan Materi & $1,2,3$ & 15 & 10 & Layak \\
Penyajian Materi & $4,5,6,7$ & 20 & 12 & Layak \\
Bahasa & $8,9,10$ & 15 & 12 & Layak \\
Jumlah Keseluruhan & & 50 & 34 & $34 / 50=$ \\
& & & & $68 \%$ \\
\hline
\end{tabular}


Dila Handayani, Fitry Wahyuni : Optimalisasi Pengembangan ...

Tabel 4. Hasil Validasi Ahli Media Bahan Ajar Digital Book

\begin{tabular}{lllll}
\hline $\begin{array}{l}\text { Krite ria } \\
\text { Penilaian }\end{array}$ & Nomor & $\begin{array}{l}\text { Jumlah } \\
\text { Skor/Aspek }\end{array}$ & $\begin{array}{l}\text { Score Yang } \\
\text { Dicapai }\end{array}$ & Klasifikasi \\
\hline Konten/Isi & $1,2,3$ & 15 & 15 & Sangat Layak \\
$\begin{array}{l}\text { Desain/ } \\
\text { Tampilan }\end{array}$ & $\begin{array}{l}4,5,6,7,8,9,1 \\
0,11,1\end{array}$ & 55 & 48 & Layak \\
$\begin{array}{l}\text { Penggunaan/ } \\
\begin{array}{l}\text { Penyajian } \\
\text { Bahasa }\end{array}\end{array}$ & $15,13,14$ & 10 & 10 & Sangat Layak \\
$\begin{array}{l}\text { Jumlah Keseluruhan } \\
17,18,19,20\end{array}$ & 20 & 20 & Sangat Layak \\
\hline
\end{tabular}

Tabel 5. Hasil Validasi Ahli Media dan Ahli Materi

\begin{tabular}{llll}
\hline No. & Validator & Skor & Kategori \\
\hline $\mathbf{1}$ & Ahli Materi & 68 & Layak \\
$\mathbf{2}$ & Ahli Media & 93 & $\begin{array}{l}\text { Sangat } \\
\text { Layak }\end{array}$ \\
& Jumlah & $\mathbf{1 6 1}$ & \\
& Rata-rata & $\mathbf{8 0 , 5 \%}$ & \\
\hline & Kategori & Layak & \\
\hline
\end{tabular}

Berdasarkan tabel 5. diperoleh rata-rata total untuk validasi digital book pada Optimalisasi Pengembangan Perencanaan Pembelajaran Perkuliahan Daring Mata Kuliah Bahasa Indonesia Universitas Tjut Nyak Dhien adalah $80,5 \%$. Dengan mengacu pada kriteria tersebut maka dapat disimpulkan bahwa Hasil penelitian yang diperoleh yakni hasil validasi ahli terhadap Kontrak kuliah, SAP, RPS, Evaluasi dan Bahan Ajar Digital Book layak digunakan dalam Optimalisasi Pengembangan Perencanaan Pembelajaran Perkuliahan Daring Mata Kuliah Bahasa Indonesia Universitas Tjut Nyak Dhien. Hasil kelayakan di dukung pendapat Amri (2013:207) yang menyatakan bahwa, aspek validitas mengacu pada sejauh mana desain perangkat yang dikembangkan.

\section{Pembahasan}

Pada tahap implementasi kegiatan yang dilakukan adalah mengimplementasikan Perangkat Perkuliahan mulai dari Kontrak Kuliah, SAP \& RPS, Bahan Ajar ebook Bahasa Indonesia pada mahasiswa Program Studi Sistem Informasi Fakultas Teknik Universitas Tjut Nyak Dhien. Kontrak Kuliah, SAP \& RPS, Bahan Ajar e-book Bahasa Indonesia yang telah dikembangkan melalui revisi yang diterima diterapkan langsung pada proses perkuliahan. Akan tetapi dikarenakan kondisi Covid 19 
mahasiswa tidak diizinkan oleh pihak kampus untuk hadir di kelas. Maka dari itu, tahap implementasi yang dilakukan melalui daring melalui media Zoom dan Google Classroom Hasil yang diperoleh pada hasil perkuliahan mahasiswa dari beberapa pertemuan memperoleh peningkatan nilai UTS dengan presentasu $94 \%$.

\section{SIMPULAN}

Hasil penelitian yang diperoleh yakni hasil validasi ahli terhadap Kontrak kuliah, SAP, RPS, Evaluasi dan Bahan Ajar Digital Book layak digunakan dalam Optimalisasi Pengembangan Perencanaan Pembelajaran Perkuliahan Daring Mata Kuliah Bahasa Indonesia Universitas Tjut Nyak Dhien. Dengan hasil Hasil Riview Validator Ahli Perencanaan Pembelajaran Perkuliahan Daring Mata Kuliah Bahasa Indonesia Universitas Tjut Nyak Dhien tahap 1, untuk kontral kuliah, SAP, RPS dan Evaluasi mendapat jumlah 33 dengan persentasi $76,7 \%$ dan katagori layak. Hasil Riview Validator Ahli Perencanaan Pembelajaran Perkuliahan Daring Mata Kuliah Bahasa Indonesia Universitas Tjut Nyak Dhien tahap 2, untuk kontral kuliah, SAP, RPS dan Evaluasi mendapat jumlah 43 dengan persentasi $100 \%$ dan katagori sangat layak. Serta rata-rata total untuk validasi digital book pada Optimalisasi Pengembangan Perencanaan Pembelajaran Perkuliahan Daring Mata Kuliah Bahasa Indonesia Universitas Tjut Nyak Dhien adalah $80,5 \%$.

\section{DAFTAR RUJUKAN}

Amri, Sofia. 2013. Development \& Learning Models in the 2013 Curriculum. Jakarta: Library Achievement. p.207

Sugiyono. 2015. Metodologi Penelitian Kuantitatif, Kualitatif dan $R \& D$. Bandung: Alfabeta.

Syahbana, Ali. 2012. Improving Students' Mathematical Critical Thinking Ability SMP through Contextual Teaching and Learning Approach. Journal Edumatica, 2(1): 45-57. 